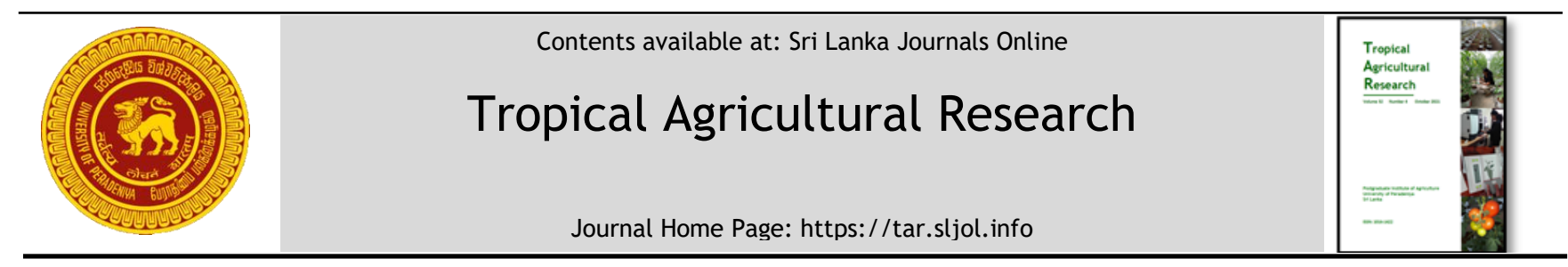

\title{
Bioconversion of Fruit Wastes of Papaya, Watermelon, and Banana into Single Cell Protein Production
}

\author{
P. Thiviya ${ }^{*}$, R. Kapilan ${ }^{2}$; T. Madhujith ${ }^{3}$ \\ ${ }^{1}$ Postgraduate Institute of Agriculture, University of Peradeniya, Peradeniya, 20400, Sri Lanka \\ ${ }^{2}$ Department of Botany, University of Jaffna, Jaffna, Sri Lanka \\ ${ }^{3}$ Department of Food Science \& Technology, University of Peradeniya, Peradeniya, 20400, Sri Lanka
}

\section{ARTICLE INFO}

Article history:

Received: 29 July 2020

Revised version received: 17 September 2021

Accepted: 22 September 2021

Available online: 01 October 2021

\section{Keywords:}

Banana peel

Liquid state fermentation

Papaya peel

Single cell protein

Watermelon peel

\section{Citation:}

Thiviya, P., Kapilan, R. and Madhujith, T. (2021). Bioconversion of fruit wastes of papaya, watermelon, and banana into single cell protein production Tropical Agricultural Research, 32(4): 503-514.

DOI: http://doi.org/10.4038/tar.v32i4.8518

Thiviya, $\mathrm{P}$,

https://orcid.org/0000 - 0001-6980-5155

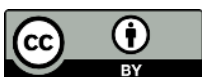

\section{ABSTRACT}

A large quantity of fruit waste is generated in the country which goes into waste creating a number of environmental issues. This fruit waste can effectively be utilized as a substrate to produce single cell proteins. The objective of the present study was to produce single cell proteins from locally available papaya (Carica papaya), watermelon (Citrullus lanatus) and banana fruit (Musa spp.) peel using natural palmyrah (Borassus flabellifer) toddy yeast under liquid state fermentation system. Physiochemical properties: Total Soluble Solids (TSS), reducing sugar, $\mathrm{pH}$, moisture, protein, fat and ash contents of peel samples were determined. Each extract was separately filtered and diluted to $10 \%$ with distilled water and subsequently autoclaved. The sterilized peel extracts were inoculated with $5 \mathrm{~mL}$ natural palmyrah toddy in triplicate and allowed for fermentation in a shaking incubator at $100 \mathrm{rpm}$ for $48 \mathrm{~h}$. The sediment was collected by centrifugation, oven dried and then the dry weight and protein content were determined. Papaya peel extract generated significantly $(\mathrm{p}<0.05)$ higher amount of protein $(52.4$ $\pm 0.4 \%)$ followed by watermelon $(45.2 \pm 0.7 \%)$ and banana $(30.4$ $\pm 0.6 \%$ ). The fermentation conditions were optimized for SCP production using papaya peel. Protein content observed at $10 \%$ substrate concentration, $\mathrm{pH} 5.0$, at $25{ }^{\circ} \mathrm{C}$ and $24 \mathrm{~h}$ of fermentation were $55.6 \pm 0.4 \%, 53.2 \pm 0.7 \%, 54.5 \pm 3.6 \%$ and $59.1 \pm 0.8 \%$, respectively. Based on the results obtained, papaya peel extract is found to be the best substrate for the SCP production. Natural and locally available papaya peel waste could be a good source for the production of protein-rich cell biomass using liquid state fermentation system by natural toddy yeast of palmyrah.

\footnotetext{
*Corresponding author: thiviya904@gmail.com
} 


\section{INTRODUCTION}

Food industry in Sri Lanka generates a large quantity of waste and improper management of waste often constitutes a public health risk and leads to environmental issues. Single Cell Protein (SCP) is a value-added product that can be derived from various waste materials via microbial fermentation and helps reduce the negative environmental impact (Spalvins et al., 2018). Increasing world deficiency of protein is becoming a major problem with the fast-growing world population. SCP can be a new, alternate and unconventional protein source in order to meet the nutritional requirements. SCP refers to the dead, dried microbial cell or total protein extracted from pure microbial cell culture; algae, bacteria, filamentous fungi, yeast, which grown on different carbon sources (Goldberg, 1985). SCP from agrowaste material has gained increased attention in the recent past as a relatively cheap protein source.

SCP, also known as microbial protein has become popular for its various benefits such as high protein content (nearly $60-82 \%$ of dry cell weight), high efficiency in substrate conversion, high productivity as it produces from fast growth rate of microorganisms and it is neither seasonal nor climate dependent. SCP does not require a wide variety of raw materials while microorganisms can be used for SCP production (Nasseri et al., 2011; Suman et al., 2015). SCP is rich in certain essential amino acids such as lysine and methionine which are limiting in most plant and animal foods (Suman et al., 2015). Moreover, bioconversion of these waste materials to protein-rich food can reduce the cost of SCP production significantly (Mahan et al., 2018).

Carbohydrate substrates such as whey, orange peel residue, sweet orange residue, sugarcane bagasse, paper mill waste, rice husk, wheat straw residue, cassava waste, sugar beet pulp, coconut waste, grape waste, and mango waste (Mensah and Twumasi, 2017) are widely used for SCP production due to the fact that building blocks of carbohydrates are natural microbial substrates (Ugalde and Castrillo, 2002). These fruit wastes are rich in fermentable sugars and other basic nutrients that support microbial growth thus fruit processing wastes are important substrate for production of microbial proteins (Adoki, 2008; Nasseri et al., 2011; Anamika and Prahlad, 2017).

Intensive food production causes generation of agricultural wastes in high quantities and improper management of these wastes can constitute a public health risk and environmental problems. It is reported that the postharvest losses of fruits vary between $20-40 \%$ with the highest loss recorded for papaya in Sri Lanka (Ruvini et al., 2018). Waste arising from mango is $30-50 \%$ while that of banana and orange are 20 and $30-50 \%$, respectively (Ruvini et al., 2018). The main solid waste generated in the fruit processing industry is fruit peel. Discarding these massive quantities of waste may result in critical environmental issues. Microorganisms could utilize these cheap and abundant agro-waste to produce SCP thus, it can help minimize the effect of organic waste disposal into the environment (Mensah and Twumasi, 2017).

Various microorganisms are used for the production of SCP: bacteria (Cellulomonas, Alcaligenes), algae (Spirulina, Chlorella), molds (Trichoderma, Fusarium, Rhizopus) and yeast (Candida, Saccharomyce) (Nasseri et al., 2011). Yeast is suitable for SCP production because of its superior nutritional quality, high lysine content, large size making them easier to harvest and ability to grow under low $\mathrm{pH}$ conditions (Nasseri et al., 2011). Moreover, the yeast and fungi are the most accepted and utilized microorganisms for SCP production because of the long history of using them in traditional fermentation (Zhou et al., 2017). Yeast also has its own limitations, such as comparatively lower growth rates compared to bacteria (2-5 h), lower protein (45- 65\%) and methionine contents (Gabriel et al., 2014). Yeast has lower methionine content than bacteria which can be offset by the addition of methionine to the final end product (Srividya et al., 2013).

Present study used palmyrah toddy as the source of yeast. The sap derived from tapping of the palmyrah inflorescence of the tree is called toddy. Palmyrah toddy contains a mixed culture of yeast and bacteria. Among yeasts, the predominant and best alcoholic fermenter is Saccharomyces cerevisiae (Theivendirarajah and Chrystopher, 1987).

High nucleic acid content and low cell wall digestibility are the two most important factors limiting the nutritional value of yeast for human consumption. Purine compound in nucleic acid is metabolized into uric acid, and its high concentration may result in gout and renal calculi. Therefore, nucleic acid content of SCP must be reduced below 2\% (Nasseri et al., 2011).

Solid, semisolid and submerged fermentation methods are used for cultivation of microorganism for SCP production (Bajpai, 2017) while the submerged method was used in the present study. Liquid culture is ideal for the growing of bacteria or yeasts that require high moisture content (Fontana 
Capalbo et al., 2001). Soluble sugars, molasses, liquid media and fruit and vegetable juices are some common substrates used in submerged fermentation (Subramaniyam and Vimala, 2012). The advantage of the submerged technique is the easy purification of products. The submerged culture fermentation requires high capital investment and involve a high operating cost. Furthermore, it is important to maintain strict aseptic conditions in submerged culture fermentation method. A large quantity of post fermentation waste is generated, hence effluents would lead to pollution of the environment (Bajpai, 2017).

After fermentation, the biomass is washed, dried and mixed with animal feed or used directly. Drying can be done by drum drying, spray drying or freeze drying. Thus, the pre-concentration can be done by centrifugation following by heating, filtration and evaporation (Bajpai, 2017; Theodore et al., 1970). The effective use of microbial protein for human food requires destruction of indigestible cell walls and reduction of nucleic acid content (Nasseri et al., 2011). Cell walls can be disrupted by autolysis, chemical disruption with detergents, hydrolysis, mechanical methods or combinations of these methods (Garcia-Garibay et al., 2003; Nasseri et al., 2011). Adedayo et al. (2011) reported that the nucleic acid content can be reduced in SCP with one or all of the treatments: chemical treatment with sodium hydroxide, treatment of cells with $10 \%$ sodium chloride, activation of endogenous nucleases during final stage of microbial biomass production and thermal shock.

SCP from agro-waste material has gained increased attention in the recent past as a relatively cheap protein source. SCP has a wide application in animal and human food supplement and has been successfully commercialized in Japan, Russia, France, Finland and England for decades (Ritala et al., 2017). It is used in the formulation of animal feed for fattening calves, poultry, pigs and fish breeding. SCP is widely used in food industry as flavour carriers and vitamin carriers, emulsifying aids and to improve the nutritive value of baked products, in soups, in ready-to-serve meals and in diet recipes (Suman et al., 2015). Furthermore, SCP is being manufactured under different commercial names such as Brovile ${ }^{\circledR}$, Marmite ${ }^{\circledR}$, Pruteen ${ }^{\circledR}$ etc (Ritala et al., 2017).

The SCP is an important source of essential amino acids, carbohydrates, lipids and nucleic acids. The composition of SCP depends on the microorganism and the substrate used for the production (Suman et al., 2015). The method of harvesting, drying and processing also has an effect on the nutritive value of the finished product (Bajpai, 2017).

Studies addressing the possibility of exploring different cost-effective fruit wastes for SCP production are scanty. In this backdrop, the present study was carried out to select the best fruit peel for SCP production, optimize fermentation conditions for the production of SCP from papaya, watermelon and banana peel waste using natural palmyrah toddy yeast under Liquid State Fermentation (LSF) and to obtain the optimum protein yield.

\section{METHODOLOGY}

\section{Materials}

Papaya, watermelon and banana peel were obtained from fruits purchased from the local markets in Jaffna, Sri Lanka. Palmyrah toddy was collected from Palm Products Distilleries, Thikkam, Jaffna, Sri Lanka. Palmyrah toddy was collected from mature palm using sterile vessels in order to use as the source of natural fermentative yeast and bacteria.

\section{Physico-chemical analysis of papaya, watermelon and banana peel}

Cleaned, washed papaya, watermelon and banana peel were weighed and the moisture, protein, fat and ash contents were determined using AOAC (2006) methods. Moisture content was determined by oven drying at $105{ }^{\circ} \mathrm{C}$, crude protein content was determined by Kjedhal method, crude fat content was determined by continuous extraction in a Soxhlet apparatus (LabKits-SZF-06A, China) for $6 \mathrm{~h}$ using petroleum ether as solvent and the ash content was calculated by keeping the pre weighed sample in a muffle furnace (Hobersal-HD-330PA, Spain) at $550^{\circ} \mathrm{C}$ for $6 \mathrm{~h}$. Total carbohydrate content was determined by difference (BeMiller, 2010).

The total soluble solids (TSS) and $\mathrm{pH}$ were determined by refractometer (Atago - DR-A1, Japan) and pH (Ohaus - Starter 2100, USA) meter respectively. The reducing sugar content was determined by a spectrophotometric method using 3,5-dinitrosalicylic acid (DNS) (Miller, 1959). The absorbance was read at 540 using spectrophotometer (UVmini-1240, Germany). 


\section{Preparation of culture media}

The collected peels were cleaned and washed with distilled water and macerated separately using a blender into slurry and filtered through Whatman No 1 filter paper. The TSS and $\mathrm{pH}$ of each extract were determined using a refractometer (Atago DR-A1, Japan) and pH meter (Ohaus - Starter 2100, USA), respectively. Fruit waste medium was prepared by mixing $100 \mathrm{~mL}$ of fruit juice, $1.0 \mathrm{~g}$ of $\mathrm{KH}_{2} \mathrm{PO}_{4}, 0.5 \mathrm{~g} \mathrm{MgSO}_{4} .7 \mathrm{H}_{2} \mathrm{O}, 0.1 \mathrm{~g}$ of $\mathrm{NaCl}, 0.1 \mathrm{~g} \mathrm{CaCl}_{2}$ and $900 \mathrm{~mL}$ distilled water (Dhanasekaran et al., 2011). Then the medium was sterilized in autoclave at $121^{\circ} \mathrm{C}$ at $15 \mathrm{psi}$ for $15 \mathrm{~min}$. The sterilized papaya peel substrate was stored at $4^{\circ} \mathrm{C}$.

\section{Liquid state fermentation process and production of SCP}

Sterilized peel (50 mL) was transferred into presterilized conical flasks in triplicates under sterile conditions. Each sterilized medium was inoculated with $5 \mathrm{~mL}$ of fresh palmyrah toddy sample (1.63 \pm $0.15) \times 10^{6}$ cells $/ \mathrm{mL}$ ) and allowed for fermentation in a shaking incubator (Lab companion SI-600, USA) at a speed of $100 \mathrm{rpm}$ for specific time and temperature. At the end of fermentation, sediment was centrifuged (1252×g for $20 \mathrm{~min})$ and the residue was oven dried $\left(50^{\circ} \mathrm{C}\right.$ for $\left.16 \mathrm{~h}\right)$ and the dry weight was measured. Protein content was determined on the basis of total nitrogen content $(\mathrm{N} \times 6.25)$ using Kjeldahl method as per the protocol explained in AOAC, 2006 (Dhanasekaran et al., 2011).

\section{Selection of the best substrate}

Sterilized diluted papaya, watermelon and banana peel extracts were used without any inorganic supplement added to determine the best substrate for the production of SCP. The liquid state fermentation was carried out in the shaking incubator at a speed of $100 \mathrm{rpm}$ for $48 \mathrm{~h}$ at $28{ }^{\circ} \mathrm{C}$ in triplicate. After $48 \mathrm{~h}$, sediment was centrifuged (1252 $\mathrm{g}$ for $20 \mathrm{~min}$ ) and oven dried $\left(50{ }^{\circ} \mathrm{C}\right.$ for $\left.16 \mathrm{~h}\right)$ and the dry weight was measured. Protein content was determined using Kjeldahl method and the results were compared.

\section{Optimization of fermentation conditions}

The fermentation conditions: fermenting time, temperature, $\mathrm{pH}$ and substrate concentration $(\mathrm{v} / \mathrm{v}$ $\%)$ of papaya peel substrate were optimized for SCP yield and its protein content. The conditions were optimized by changing one factor at a time while keeping the other variables constant. All the experiments were carried out in triplicate in a shaking incubator (Lab Companion SI-600, USA) at $100 \mathrm{rpm}$. The different substrate concentrations (v/v \%) of 1 to $5,10,50$ and $100 \%$ were analysed to determine the optimum conditions at $28{ }^{\circ} \mathrm{C}, \mathrm{pH}$ 5.0 for 3 days. To determine the optimum $\mathrm{pH}$, fermentation was carried out in the range of $\mathrm{pH} 3.0$ to 5.5 at $28{ }^{\circ} \mathrm{C}$, at a concentration of $10 \%(\mathrm{v} / \mathrm{v})$ for 3 days. To determine the optimum temperature, the fermentation was carried out in the temperature ranging from $25{ }^{\circ} \mathrm{C}$ to $40{ }^{\circ} \mathrm{C}$ at $10 \%$ (v/v) concentration, $\mathrm{pH} 5.0$ for 3 days. To determine the optimum time, fermentation was carried out at $10 \%(\mathrm{v} / \mathrm{v})$ concentration at $\mathrm{pH} 5.0$ at $25^{\circ} \mathrm{C}$ for 7 consecutive days. Dry biomass and the protein content were determined in each treatment and the results were compared.

\section{Statistical analysis}

All the experiments were carried out in triplicates and the results were presented as the average of triplicates \pm standard deviation. Minitab 17 (minitab inc., state college, pa, usa) statistical package was used to execute all statistical analysis. The data were analysed using anova. Tukey's multiple comparison test was used to determine significant differences at $\mathrm{p}<0.05$

\section{RESULTS AND DISCUSSION}

\section{Physico-chemical properties of peels}

The physico-chemical properties such as $\mathrm{pH}$, total soluble solids, reducing sugar and nutritive values of papaya, watermelon and banana peel are presented in Table 1. The growth of microorganisms depends mainly on the nutritional composition of waste materials. Locally available agro-wastes are rich in organic matter that can be used as a carbon and energy source by yeast in SCP production (Adedayo et al., 2011). Papaya peel contains high amount of reducing sugar (5.8 \pm 0.1 $\mathrm{g} / \mathrm{L})$, followed by banana $(3.1 \pm 0.4 \mathrm{~g} / \mathrm{L})$ and watermelon $(1.8 \pm 0.1 \mathrm{~g} / \mathrm{L})$. The highest ash content was observed in banana peel $(1.9 \pm 0.1 \%)$ followed by papaya $(0.5 \pm 0.0 \%)$ and watermelon $(0.3 \pm 0.3 \%)$. Furthermore, banana peel contained comparatively high quantity of protein (1.7 \pm $0.0 \%$ ), while papaya and watermelon contained $1.0 \pm 0.0 \%$ and $0.5 \pm 0.0 \%$, respectively.

The findings of the present study are comparable with those of other studies. Reducing sugar content of papaya and banana was in agreement with the results reported by Saheed (2016). Protein content of watermelon peel was comparable to results 
Table 1. Physico-chemical properties of papaya, watermelon and pineapple peel.

\begin{tabular}{lrrr}
\hline \multirow{2}{*}{ Property } & \multicolumn{2}{c}{ Fruit peel } \\
\cline { 2 - 4 } & Water-melon & Papaya & Banana \\
\hline Reducing sugar (\%) & $1.8 \pm 0.1$ & $5.8 \pm 0.1$ & $3.1 \pm 0.4$ \\
pH & $5.4 \pm 0.0$ & $5.5 \pm 0.0$ & $4.8 \pm 0.0$ \\
TSS (\%) & $3.2 \pm 0.0$ & $6.5 \pm 0.0$ & $7.1 \pm 0.0$ \\
Moisture content (\%) & $95.0 \pm 0.4$ & $91.6 \pm 0.2$ & $73.9 \pm 2.1$ \\
Ash content (\%)* & $0.3 \pm 0.0$ & $0.5 \pm 0.0$ & $1.9 \pm 0.1$ \\
Fat content (\%)* & $0.1 \pm 0.0$ & $0.1 \pm 0.0$ & $0.7 \pm 0.1$ \\
Protein content (\%) & $0.5 \pm 0.0$ & $1.0 \pm 0.0$ & $1.7 \pm 0.0$ \\
Total carbohydrate (\%)* & $4.1 \pm 0.4$ & $6.9 \pm 0.1$ & $21.8 \pm 2.2$ \\
\hline
\end{tabular}

Results are expressed as mean of triplicate \pm standard deviation.

*Values are on wet weight basis

reported by Mahnaaz et al. (2010). The protein content of papaya peel was lower than the value recorded by Mahnaaz et al. (2010). The ash content of papaya is comparable with the ash and fat content reported by Pavithra et al. (2017) while lower value was reported for protein content. It may probably be due to variations in variety, origin and maturity stage of the fruits. Proximate analysis of banana peel is supported by the findings of Emaga et al. (2007), which reported that the ash content in different varieties of banana peels varied from 6.4 to $12.8 \%$, protein content varied from 8$11 \%$ and $2.2 \%$ to $10.9 \%$ fat on dry weight basis.

Proximate analysis was carried out to assess the potential of various wastes for cost effective biomass production using palmyrah natural toddy yeast. The yeast biomass production depends on multiple factors and the carbohydrates and mineral contents are the most important of all (Bacha et al., 2011). Results of the compositional analysis indicated that papaya, watermelon and pineapple peel can be used as a potential substrate for the production of SCP due to its reasonable carbohydrate and mineral content (Mondal et al., 2012; Dhanasekaran et al., 2011).

\section{Selection of the best substrate for the SCP production}

The suitability of papaya, watermelon and banana peel on SCP production was determined based on the weight of dry mass and its protein content (Table 2). Among papaya, watermelon and banana peel extracts, papaya peel extract yielded a significantly $(\mathrm{p}<0.05)$ higher biomass $(11.7 \pm 0.8$ $\mathrm{g} / \mathrm{L})$ and protein contents $(52.4 \pm 0.4 \%)$ while lesser biomass was observed with watermelon (5.3 $\pm 0.6 \mathrm{~g} / \mathrm{L})$ and banana $(7.8 \pm 1.9 \mathrm{~g} / \mathrm{L})$ media. The highest crude protein yield was shown by papaya $(52.4 \pm 0.4 \%)$, followed by watermelon $(45.2 \pm$ $0.7 \%$ ) and banana (30.4 $\pm 0.6 \%$ ) (Figure 1 ).

Table 2. Dry biomass and crude protein contents of SCP from papaya, watermelon and banana peel medium.

\begin{tabular}{lcr}
\hline Peel type & $\begin{array}{r}\text { Dry biomass } \\
(\mathrm{g} / \mathrm{L})\end{array}$ & $\begin{array}{r}\text { Crude } \\
\text { protein } \\
\text { content (\%) }\end{array}$ \\
\hline Watermelon & $5.3 \pm 0.6^{\mathrm{b}}$ & $45.2 \pm 0.7^{\mathrm{b}}$ \\
Papaya & $11.7 \pm 0.8^{\mathrm{a}}$ & $52.4 \pm 0.4^{\mathrm{a}}$ \\
Banana & $7.8 \pm 1.9^{\mathrm{b}}$ & $30.4 \pm 0.6^{\mathrm{c}}$ \\
\hline
\end{tabular}

Results are expressed as mean of triplicate \pm standard deviation

Means in the same column that do not share the same letter are significantly different

Based on the results obtained, papaya peel extract can be considered the best substrate for the SCP production among the three peel extracts studied. Higher reducing sugar content and protein content in papaya peel waste would favour the higher yield of SCP (Table 1). Watermelon skin could not support higher growth of yeast biomass, may due to high water content of watermelon skin (Mahnaaz et al., 2009). 


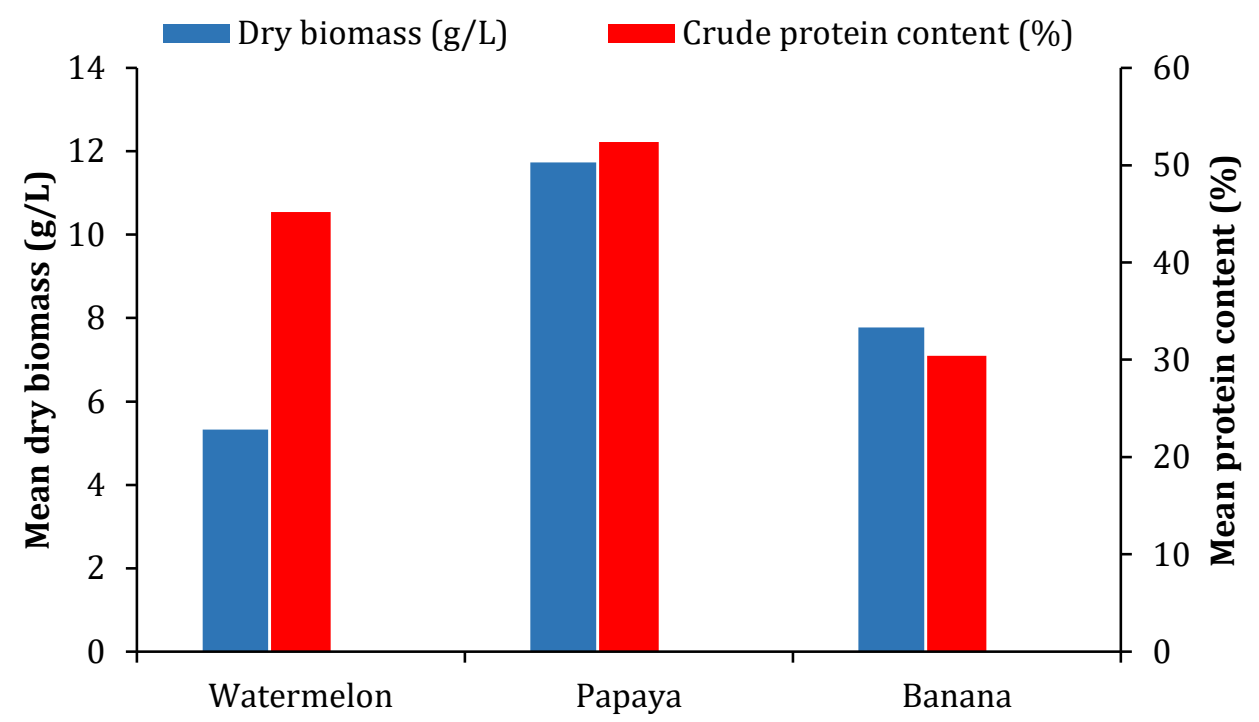

Figure 1: Dry biomass and crude protein contents of SCP from papaya, watermelon and banana peel medium

\section{Optimization of fermentation conditions}

To optimize the process of SCP production from papaya peel extract in liquid state fermentation, parameters such as substrate concentration, $\mathrm{pH}$, temperature and fermentation time were considered as they have an effect on the liquid state fermentation process. The effect of substrate concentration $(\mathrm{v} / \mathrm{v}, \%)$ on dry biomass and protein content in papaya peel medium is shown in Table 3.

Table 3. Effect of substrate concentration on dry biomass production and protein content

\begin{tabular}{crr}
\hline $\begin{array}{c}\text { Conce. } \\
(\mathbf{v} / \mathbf{v}, \mathbf{\%})\end{array}$ & $\begin{array}{r}\text { Dry biomass } \\
\text { content (g/L) }\end{array}$ & $\begin{array}{r}\text { Protein } \\
\text { content (\%) }\end{array}$ \\
\hline 1 & $08.0 \pm 4.0^{\mathrm{b}}$ & $21.0 \pm 1.2^{\mathrm{f}}$ \\
2 & $15.5 \pm 4^{\mathrm{a}, \mathrm{b}}$ & $26.3 \pm 1.1^{\mathrm{e}}$ \\
3 & $16.5 \pm 0.5^{\mathrm{a}, \mathrm{b}}$ & $30.4 \pm 1.3^{\mathrm{d}}$ \\
4 & $18.4 \pm 0.6^{\mathrm{a}}$ & $32.1 \pm 1.0^{\mathrm{d}}$ \\
5 & $23.3 \pm 0.3^{\mathrm{a}}$ & $45.3 \pm 0.9^{\mathrm{c}}$ \\
10 & $24.5 \pm 1.0^{\mathrm{a}}$ & $55.6 \pm 0.4^{\mathrm{a}}$ \\
50 & $23.3 \pm 6.9^{\mathrm{a}}$ & $52.4 \pm 2.0^{\mathrm{a}, \mathrm{b}}$ \\
100 & $19.3 \pm 1.7^{\mathrm{a}}$ & $50.3 \pm 1.3^{\mathrm{b}}$ \\
\hline
\end{tabular}

Means in the same column that do not share the same letter are significantly different.

Results are expressed as mean of triplicate \pm standard deviation.

Significantly $(\mathrm{p}<0.05)$ higher protein content $(55.6$ $\pm 0.4 \%$ ) was obtained at $10 \%$ concentration while the least protein content (21.0 $\pm 1.2 \%)$ was obtained at $1 \%$. Similar observations have also been reported earlier by Jaganmohan et al. (2013). When the concentration of substrate was increased up to $10 \%$ there was an increase in protein content of the biomass. There was no significant differences in biomass when used between 4 to $100 \%$ (v/v) papaya peel medium (Table 3).

The effect of $\mathrm{pH}$ on SCP production was studied. The initial $\mathrm{pH}$ affects the growth of yeast, the concentration of hydrogen ion change cell plasma membrane colloid charge consequently change the ion permeability of plasma membrane (a driving force for secondary transport). This indicates that the speed of nutrients into the cells is related to $\mathrm{pH}$ (Chen et al., 2016). The $\mathrm{pH}$ value of the fermentation process for SCP production is generally in the range of $\mathrm{pH} 4.5-5.5$ because of yeasts and filamentous fungi being acidophiles (Gao, 2012).

The maximum biomass was reported at $\mathrm{pH} 5.0$ $(23.9 \pm 1.7 \mathrm{~g} / \mathrm{L})$ and $4.5(22.5 \pm 1.0 \mathrm{~g} / \mathrm{L})$. Significantly $(\mathrm{p}<0.05)$ higher protein content $(53.2$ $\pm 0.7 \%$ ) was recorded at $\mathrm{pH} 5.0$ as per Tukey's multiple comparison test (Table 4).

Results of Tukey's multiple comparison test (Table 5) shows that there is no significant difference existed in between the mean protein content at 25 ${ }^{0} \mathrm{C}$ and $30{ }^{\circ} \mathrm{C}$. The maximum protein content was observed at $25{ }^{0} \mathrm{C}$ for $10 \%(\mathrm{v} / \mathrm{v})$ papaya peel medium which accounted for $54.5 \pm 3.6 \%$ (Figure 4). 


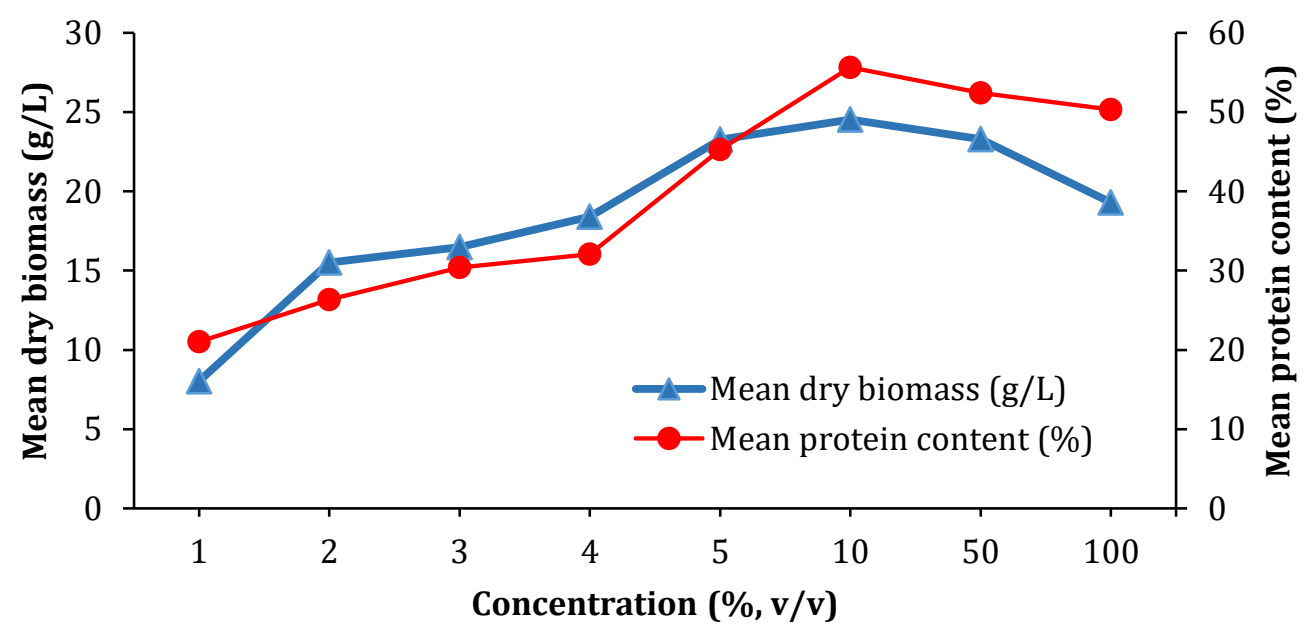

Figure 2. Effect of substrate concentration (v/v \%) on the dry biomass and protein content of SCP produced by using papaya peel medium in liquid state fermentation.

Table 4. Effect of pH on dry biomass production and protein content

\begin{tabular}{lrr}
\hline pH & $\begin{array}{r}\text { Dry biomass } \\
\text { content (g/L) }\end{array}$ & $\begin{array}{r}\text { Protein } \\
\text { content (g) }\end{array}$ \\
\hline 3.0 & $14.6 \pm 1.0^{\mathrm{d}}$ & $44.8 \pm 0.3^{\mathrm{d}}$ \\
3.5 & $16.9 \pm 2.6^{\mathrm{c}, \mathrm{d}}$ & $45.1 \pm 0.7^{\mathrm{d}}$ \\
4.0 & $20.2 \pm 0.9^{\mathrm{a}, \mathrm{c}}$ & $47.6 \pm 0.2^{\mathrm{c}}$ \\
4.5 & $22.5 \pm 1.0^{\mathrm{a}, \mathrm{b}}$ & $49.4 \pm 0.2^{\mathrm{b}}$ \\
5.0 & $23.9 \pm 1.7^{\mathrm{a}, \mathrm{b}}$ & $53.2 \pm 0.7^{\mathrm{a}}$ \\
5.5 & $17.8 \pm 2.9^{\mathrm{b}, \mathrm{c}, \mathrm{d}}$ & $46.9 \pm 0.2^{\mathrm{c}}$ \\
\hline
\end{tabular}

Means in the same column that do not share the same letter are significantly different.

Results are expressed as mean of triplicate \pm standard deviation.

Table 5. Effect of fermentation temperature on dry biomass production and protein content.

\begin{tabular}{lrr}
\hline $\begin{array}{l}\text { Temperature } \\
(\mathbf{o} \mathbf{C})\end{array}$ & $\begin{array}{r}\text { Dry biomass } \\
\text { content (g/L) }\end{array}$ & $\begin{array}{r}\text { Protein } \\
\text { content (g) }\end{array}$ \\
\hline 25 & $15.3 \pm 2.0^{\mathrm{b}}$ & $54.5 \pm 3.6^{\mathrm{a}}$ \\
30 & $25.6 \pm 2.6^{\mathrm{a}}$ & $50.5 \pm 0.7^{\mathrm{a}, \mathrm{b}}$ \\
35 & $14.7 \pm 2.1^{\mathrm{b}}$ & $44.6 \pm 2.3^{\mathrm{b}}$ \\
40 & $19.7 \pm 4.5^{\mathrm{a}, \mathrm{b}}$ & $37.8 \pm 2.3^{\mathrm{c}}$ \\
\hline
\end{tabular}

Means in the same column that do not share the same letter are significantly different.

Results are expressed as mean of triplicate \pm standard deviation

Further, the results (Figure 3) showed that biomass and crude protein production increased from $\mathrm{pH}$ of 3 to 5 and reached maximum biomass and crude protein yield at pH 5 (23.9 $\pm 1.7 \mathrm{~g} / \mathrm{L}$ and
$53.2 \pm 0.7 \%$ ). Lower biomass and protein contents were recorded at $\mathrm{pH} 3.0$ as metabolic activities of yeast inhibited at lower initial $\mathrm{pH}$ condition. Statistical analysis of mean value of biomass and protein content between each treatment reveals $\mathrm{pH} 5.0$ would be an optimum $\mathrm{pH}$ for SCP production by using $10 \%$ papaya peel medium. Similar observation was recorded by Yousufi, (2012) for SCP produced from okara-wheat grit substrates using Rhizopus oligosporus and Aspergillus oryzae.

Temperature is one of the most influencing factors on the growth of microorganisms and thus on the yield and productivity in the SCP production (Reihani and Khosravi-Darani, 2019). The temperature of $25-27^{\circ} \mathrm{C}$ is the most common temperature used for the incubation of different microorganisms (Reihani and Khosravi-Darani, 2019). The effect of fermentation temperature on SCP production was studied in the present study (Table 5).

The biomass was increased from the fermentation temperature of $25{ }^{0} \mathrm{C}$ to $30{ }^{0} \mathrm{C}$. Significantly $(\mathrm{p}<0.05)$ higher biomass production for papaya peel medium was recorded at $30{ }^{\circ} \mathrm{C}(25.6 \pm 2.6$ $\mathrm{g} / \mathrm{L})$. When the temperature further increased above $30{ }^{0} \mathrm{C}$, there was a drop in the yield of biomass (Table 5). Munawar et al. (2010) also reported that yield of Candida utilis biomass in liquid fermentation increased from $20{ }^{\circ} \mathrm{C}$ to $30{ }^{\circ} \mathrm{C}$ and then decreased with temperature. Normally high temperature inactivates the enzymes of the metabolic pathway while low temperature may not permit flow of nutrient across cell membrane, resulting in high demand for maintenance energy. 


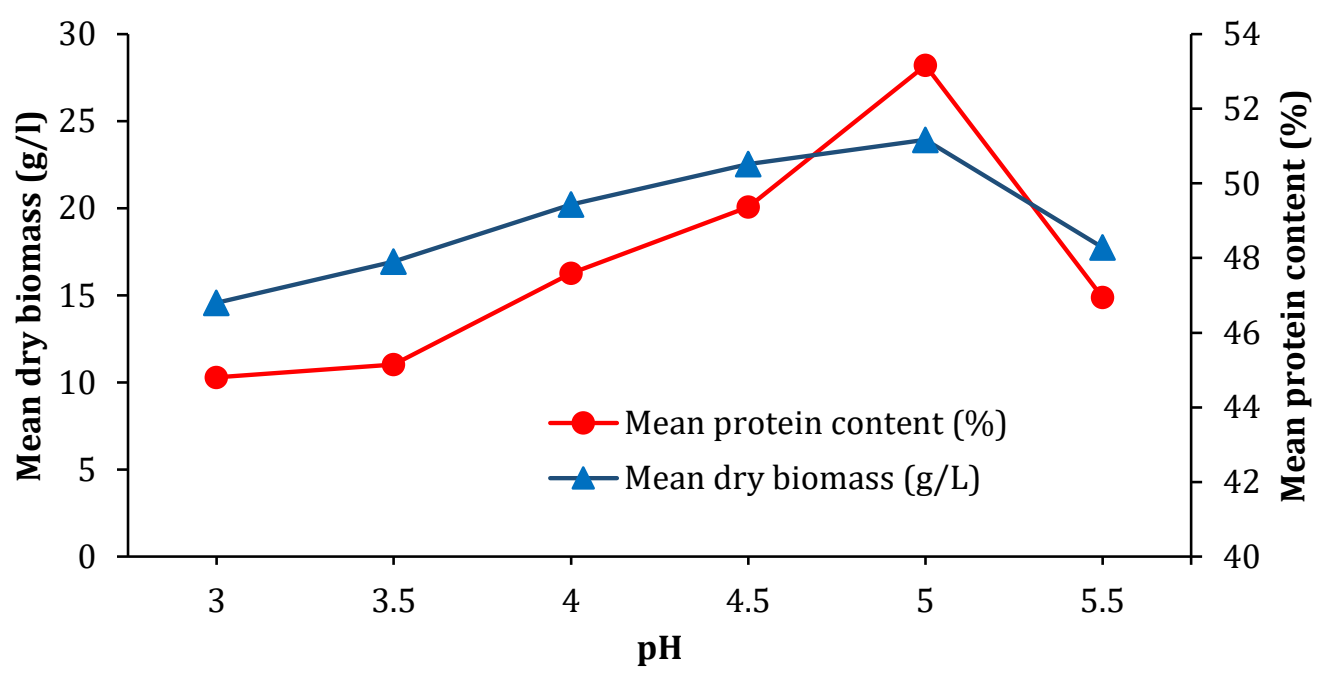

Figure 3. Effect of pH on biomass production dry biomass and protein content of SCP produced by using papaya peel medium in liquid state fermentation.

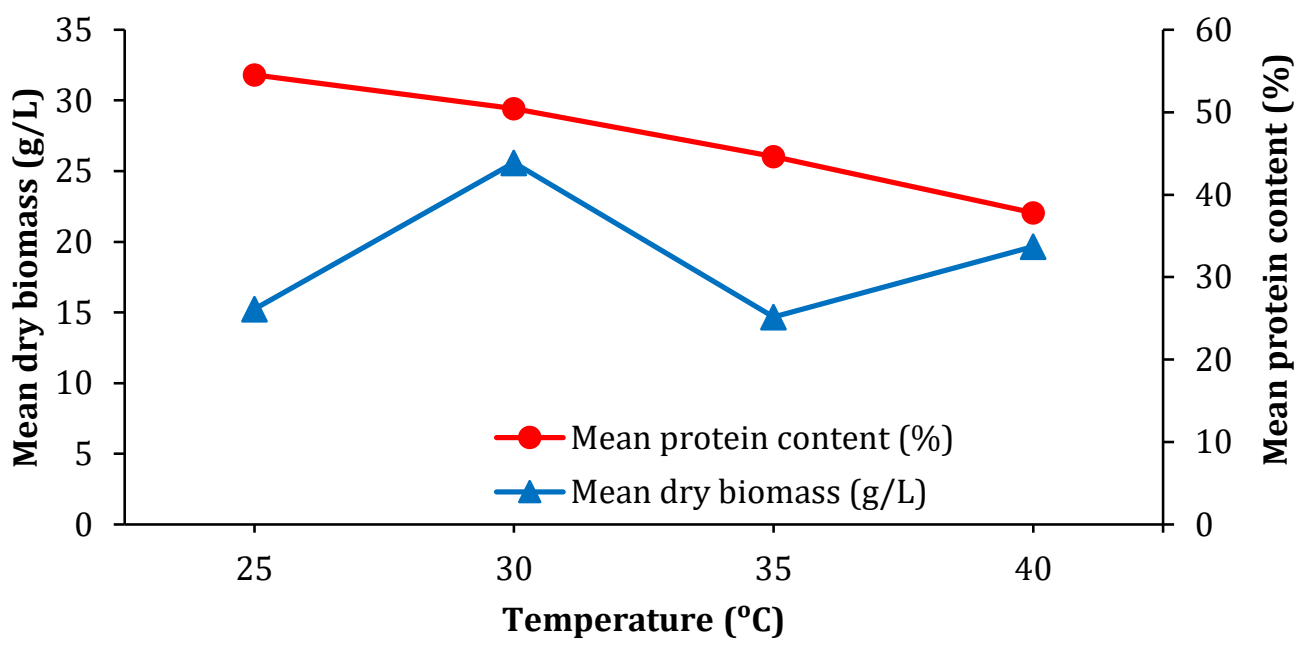

Figure 4. Effect of fermentation temperature on dry biomass and protein content of SCP produced by using papaya peel medium in liquid state fermentation.

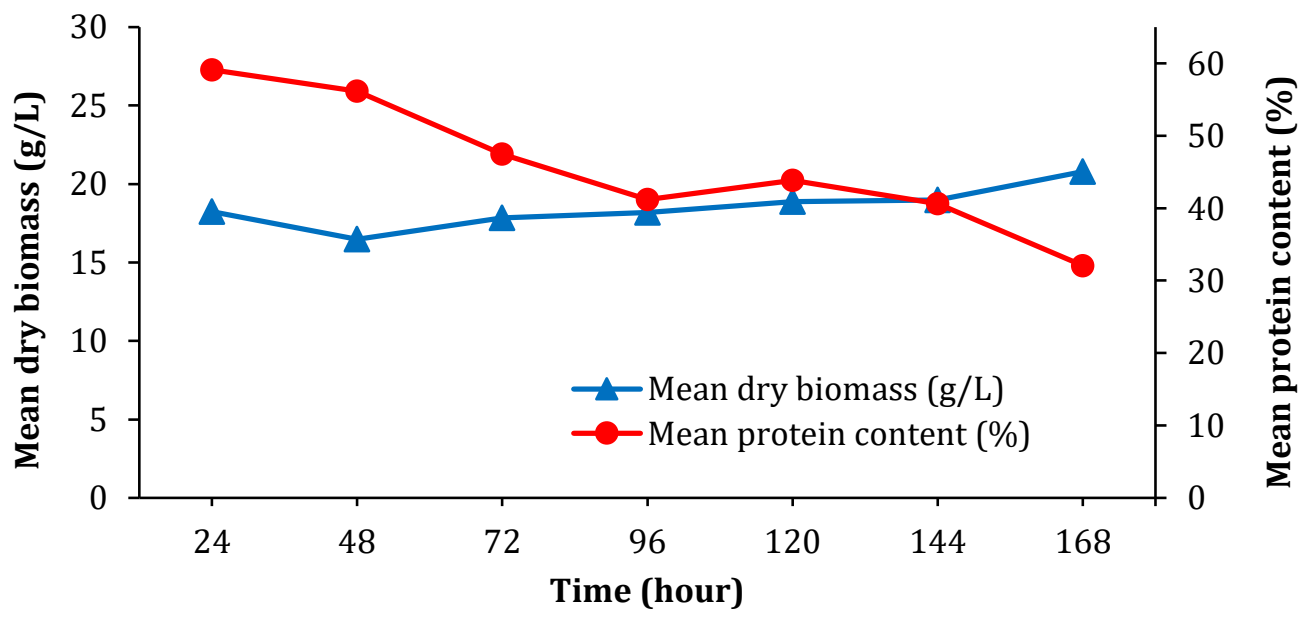

Figure 5. Effect of fermentation time on the dry biomass and protein content of SCP produced by using papaya peel medium in liquid state fermentation. 
The effect of fermentation time on SCP production was studied. The highest biomass production for papaya peel medium was recorded after 168 hour $(20.8 \pm 2.2 \mathrm{~g} / \mathrm{L})$ of fermentation and the significantly $(\mathrm{p}<0.05)$ higher protein content was recoded after $24 \mathrm{~h}$ of fermentation (59.1 $\pm 0.8 \%)$ (Table 6).

Table 6. Effect of fermentation time on dry biomass production and protein content.

\begin{tabular}{lcc}
\hline Time (h) & $\begin{array}{c}\text { Dry biomass } \\
\text { content (g/L) }\end{array}$ & $\begin{array}{c}\text { Protein } \\
\text { content (\%) }\end{array}$ \\
\hline 24 & $18.3 \pm 0.5^{\mathrm{a}}$ & $59.1 \pm 0.8^{\mathrm{a}}$ \\
48 & $16.5 \pm 0.8^{\mathrm{a}}$ & $56.2 \pm 1.4^{\mathrm{a}, \mathrm{b}}$ \\
72 & $17.8 \pm 0.3^{\mathrm{a}}$ & $47.5 \pm 4.5^{\mathrm{a}, \mathrm{b}, \mathrm{c}}$ \\
96 & $18.2 \pm 0.7^{\mathrm{a}}$ & $41.2 \pm 2.1^{\mathrm{c}, \mathrm{d}}$ \\
120 & $18.9 \pm 3.3^{\mathrm{a}}$ & $43.8 \pm 2.8^{\mathrm{b}, \mathrm{c}, \mathrm{d}}$ \\
144 & $19.0 \pm 1.4^{\mathrm{a}}$ & $40.6 \pm 1.9^{\mathrm{c}, \mathrm{d}}$ \\
168 & $20.8 \pm 2.2^{\mathrm{a}}$ & $32.1 \pm 11.1^{\mathrm{d}}$ \\
\hline
\end{tabular}

Means in the same column that do not share the same letter are significantly different. Results are expressed as mean of triplicate \pm standard deviation.

Results of Tukey's multiple comparison test showed that there was no significant difference in the mean biomass obtained with papaya peel medium and it is in line with the values reported by Ojokoh and Uzeh (2005). Similar observation was also reported by Mahan et al (2018) for Rhodococcus opacus. In terms of economics, $24 \mathrm{~h}$ is the optimum fermentation time which could result in lower energy cost, manpower hours and high of production.

The optimum conditions for fermentation of papaya waste using natural palmyrah toddy yeast were $24 \mathrm{~h}, 25{ }^{\circ} \mathrm{C}$, pH 5.0 and $10 \%$ (v/v). Results show that the mean biomass and protein content have been increased significantly $(p<0.05)$ after the optimization of process parameters (Table 7). Mean dry biomass was increased from $11.7 \pm 0.8$ $\mathrm{g} / \mathrm{L}$ to $23.2 \pm 2.3 \mathrm{~g} / \mathrm{L}$ while, mean protein content was increased from $52.4 \pm 0.5 \%$ to $56.1 \pm 0.4 \%$ (Figure 6).

Table 7. Comparison of mean biomass and the protein content before and after the optimization.

\begin{tabular}{lll}
\hline Condition & $\begin{array}{l}\text { Mean dry } \\
\text { biomass } \\
\text { (g/L) }\end{array}$ & $\begin{array}{l}\text { Mean } \\
\text { protein } \\
\text { content (\%) }\end{array}$ \\
\hline $\begin{array}{l}\text { Before } \\
\text { optimization }\end{array}$ & $11.7 \pm 0.8^{\mathrm{b}}$ & $52.4 \pm 0.4^{\mathrm{b}}$ \\
$\begin{array}{l}\text { After } \\
\text { optimization }\end{array}$ & $23.2 \pm 2.3^{\mathrm{a}}$ & $56.1 \pm 0.4^{\mathrm{a}}$ \\
\hline $\begin{array}{l}\text { Means in the same column that do not share the same } \\
\text { letter are significantly different. }\end{array}$ \\
$\begin{array}{l}\text { Results are expressed as mean of triplicate } \pm \text { standard } \\
\text { deviation. }\end{array}$
\end{tabular}

The above result established that papaya peel extract and palmyrah toddy yeast sample can be used to produce SCP. More than $96 \%$ of fruits and vegetables produced in Sri Lanka are locally consumed as fresh products without any value addition (Esham and Usami, 2006). In general, the nonedible portion $(10-60 \% \mathrm{w} / \mathrm{w})$ of fruits and vegetables such as peels, pods, seeds, skins, etc., are discarded into environment. The utilization of these wastes for SCP production help in controlling environmental pollution associated with their disposal and satisfy the world shortage of protein rich food (Anamika and Prahlad, 2017).

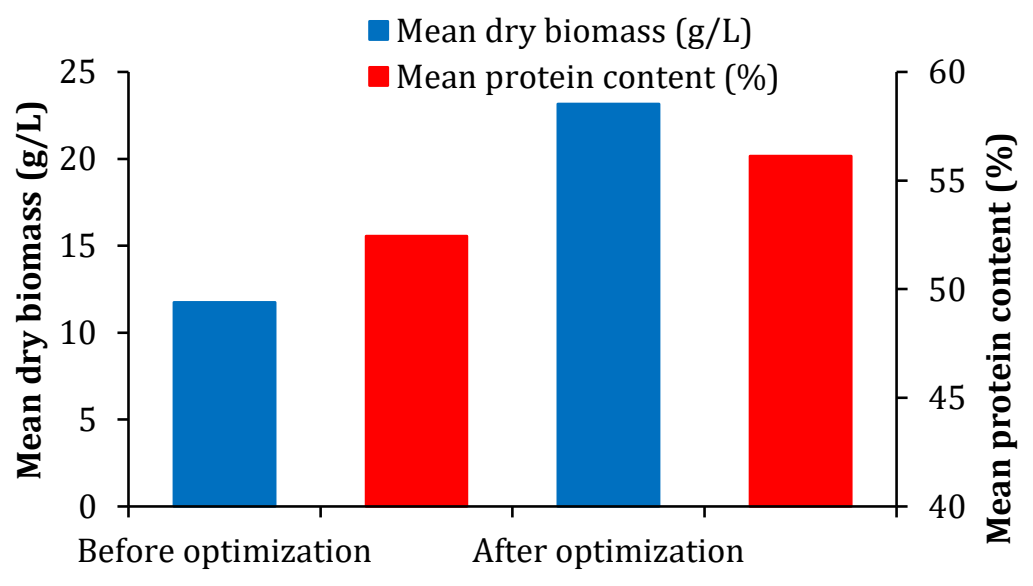

Figure 6. Mean biomass and protein content of SCP produced after the optimization. 
Table 8: Cost analysis for SCP production

\begin{tabular}{lccc}
\hline Raw material & $\begin{array}{c}\text { Fermenter with 50 mL } \\
\text { substrate (10\%) }\end{array}$ & $\begin{array}{c}\text { Fermenter with 1 L } \\
\text { substrate (10\%) }\end{array}$ & $\begin{array}{c}\text { Cost (Rs) } \\
\text { (approx.) }\end{array}$ \\
\hline Papaya peel extract & $5 \mathrm{~mL}$ & $100 \mathrm{~mL}$ & - \\
Papaya peel for extraction & $15 \mathrm{~g}$ & $300 \mathrm{~g}$ & - \\
Natural palmyrah toddy & $5 \mathrm{~mL}$ & $100 \mathrm{~mL}$ & 40 \\
Chemical for media & - & - & 1800 \\
Electrical cost & - & - & 1000 \\
\hline
\end{tabular}

Further, the effective use of microbial protein for human food requires liberation of cell proteins by destruction of indigestible cell walls and reduction of nucleic acid content (Nasseri et al., 2011). Yeast has high nucleic acid (RNA) content (6-12\% of dry weight) (Kalaichelvan \& Arul, 2019) which need to be reduced to 2\% (Nasseri et al., 2011). Yeast, algae, bacteria produce toxins during their growth period as secondary metabolites (Saeed et al., 2016). The acceptability of SCP when presented as a human food depends not only on its safety and nutritional value, but also on other factors; odour, colour, taste and texture (Smith, 2004). Hence, further extended studies need to be carried out on application of biomass as an animal feed material.

In order to fill the fermenter with $1 \mathrm{~L}$ substrate medium (10\%), $100 \mathrm{~mL}$ of papaya peel extract and $100 \mathrm{~mL}$ of natural palmyrah toddy were required. Nearly 300 g of papaya peel was used to obtain 100 $\mathrm{mL}$ of papaw waste extract. As papaya peel is obtainable from industrial waste, cost incurred is only for natural palmyrah toddy and the running cost. As transportation of the industrial waste is too expensive (Spalvins et al., 2018), in-factory process line could be the best choice. Further, no nitrogen

\section{REFERENCES}

Adedayo, M.R., Ajiboye, E.A. and Akintunde, J.K. (2011). single cell proteins: as nutritional enhancer. Advances in Applied Science Research, 2(5), 396-409.

Adoki, A. (2008). Factors affecting yeast growth and protein yield production from orange, Platinum and banana waste processing residues using Candida sp. African Journal Biotechnology, 7(3), 290-295.

Anamika, M. and Prahlad, D. (2017). Single cell protein production using various microbial mass: A review. International Journal of Advanced Research, 5(7), 2190-2194. and carbon supplements were used to grow yeast culture on selected fruit peel waste in this present study and therefore this process of SCP production becomes cheaper. This study shows that papaya peel extract would be the best substrate that can be used to produce SCP with palmyah toddy yeast. Additionally, it plays a vital role in waste management as waste materials is used as substrate (Suman et al., 2015).

\section{CONCLUSIONS}

Locally available papaya peel waste used in this study can be suggested as a best substrate compared to papaya, watermelon and banana peel for the production of SCP using natural palmyrah toddy yeast through fermentation. SCP produced using papaya peel as the substrate resulted in 52.4 $\pm 0.4 \%$ of protein with a yield of $11.7 \pm 0.8 \mathrm{~g} / \mathrm{L}$. There was a 1.07-fold increase in protein content of biomass after the optimization of fermentation condition. Recommended to have further extended studies on application of biomass as an animal feed material.

Bajpai, P. (2017). Single cell protein from lingocellulosic biomass. Springer Nature, Singapore.

BeMiller, J.N. (2010). Carbohydrate analysis. In Food analysis. Springer, Boston, MA, 147-177.

Chen, H., Zhang, Q., Shu, G.W., Li, Q.J. and Zeng, F.H. (2016). Optimization of fermentation technology for producing single cell protein from yam starch by orthogonal test. Advance Journal of Food Science and Technology, 10(11), 833-837.

Dhanasekaran, D. Lawanya, S., Saha, S., Thajuddin, N. and Panneerselvam, A. (2011). Production of single cell protein from pineapple waste. Innovative Romanian Food Biotechnology, 8, 26-32. 
Emaga, T.H., Andrianaivo, R.H., Wathelet, B., Tchango, J.T. and Paquot, M. (2007). Effects of the stage of maturation and varieties on the chemical composition of banana and plantain peels. Food chemistry, 103(2), 590-600.

Esham, M. and Usami, K. (2006). Procurement behavior of the fruit and vegetable industry in Sri Lanka. Journal of Agricultural Sciences Sri Lanka, 2(3), 36-44.

Fontana Capalbo, D.M., Valicente, F.H., Oliveira Moraes, I.D. and Pelizer, L.H. (2001). Solidstate fermentation of Bacillus thuringiensis tolworthi to control fall armyworm in maize. Electronic Journal of Biotechnology, 4(2), 910.

Gabriel, A., Victor, N. and du Preez James, C. (2014). Cactus pear biomass, a potential lignocellulose raw material for single cell protein production (SCP): A review. International Journal of Current Microbiology and Applied Sciences, 3(7), 171-197.

Gao, Y., Li, D. and Liu, Y. (2012). Production of single cell protein from soy molasses using Candida tropicalis. Annals of microbiology, 62(3), 1165-1172.

Goldberg, I. (1985). Single cell protein. SpringerVerlag, Berlin, Heidelberg, 1-160.

Jaganmohan, P., Daas, B.P. and Prasad, S.V. (2013). Production of single cell protein (SCP) with Aspergillus terrus using solid state fermentation. European Journal of Biological Sciences, 5(2), 38-43.

Kalaichelvan, P.T. and Arul, P. (2019). Bioprocess technology. Chennai: MJP Publisher, 239-346.

Mahan, K.M. et al. (2018). Production of single cell protein from agro-waste using Rhodococcus opacus. Journal of Industrial Microbiology and Biotechnology, 45(9), 795-801.

Mahnaaz, K., Saeed, S.S., Zafar, A. and Arshiya, T. (2009). Production of fungal single cell protein using Rhizopus oligosporus grown on fruit wastes. Biological Forum - An International Journal, 1(2), 26-28.

Mensah, J.K.M and Twumasi, P. (2017). Use of pineapple waste for single cell protein (SCP) production and the effect of substrate concentration on the yield. Journal of Food Processing Engineering, 40(3), 12478.

Miller, G.L. (1959). Use of dinitrosalicylic acid reagent for determination of reducing sugars. Analytical chemistry, 31(3), 426-428.

Mondal, A.K., Sengupta, S., Bhowal, J. and Bhattacharya, D.K. (2012). Utilization of fruit wastes in producing single cell. International Journal of Science, Environment and Technology, 1(5), 430 - 438.

Munawar, R.A., Irfan, M., Nadeem, M., Syed, Q.A. and Siddique, Z.H. (2010). Bio synthesis of single cell biomass of Candida utilis by submerged fermentation. Pakistan Journal of Science, 62(1), 1-5.

Nasseri, A.T., Rasoul-Amini, S., Morowvat, M.H. and Ghasemi, Y. (2011). Single cell protein; production and process. American Journal of Food Technology, 6(2), 103-116.

Ojokoh, A.O. and Uzeh, R.E. (2005). Production of Saccharomyces cerevisiae biomass in papaya extract medium. African Journal of Biotechnology, 4(11), 1281-1284.

Rao, M.B., Varma, A.J. and Deshmukh, S.S. (2010). Production of single cell protein, essential amino acids, and xylanase by Penicillium janthinellum. Bioresources, 5 (4), 2470-2477.

Reihani, S.F.S. and Khosravi-Darani, K. (2019). Influencing factors on single-cell protein production by submerged fermentation: A review. Electronic Journal of Biotechnology, 37, 34-40.

Ritala, A., Häkkinen, S.T., Toivari, M. \& Wiebe, M.G. (2017). Single cell protein-state-of-the-art, industrial landscape and patents 2001-2016. Frontiers in microbiology, 8, 2009.

Ruvini, V., Jayamini, C., Roshini, R. and Wijesooriya, N. (2018). Quality and safety issues in fruit and vegetable supply chains in Sri Lanka: A Review. Hector Kobbekaduwa Agrarian Research and Training Institute, 217, 1-120

Saeed, M., Yasmin, I., Murtaza, M.A., Fatima, I. and Saeed, S. (2016). Single cell proteins: A novel value-added food product. Pakistan Journal of Food Sciences, 26(4), 211-217.

Saheed, O.K., Jamal, P., Karim, M.I.A., Alam, M.Z. and Muyibi, S.A. (2016). Utilization of fruit peels as carbon source for white rot fungi biomass production under submerged state bioconversion. Journal of King Saud University-Science, 28(2), 143-151.

Smith, J.E. (2004). Single cell protein (SCP). In Biotechnology. 4th Ed. Cambridge University Press, UK, pp. 118-135.

Spalvins, K., Zihare, L. and Blumberga, D. (2018). Single cell protein production from waste biomass: comparison of various industrial byproducts. Energy Procedia, 147, 409-418.

Srividya, A.R., Vishnuvarthan, V.J., Murugappa, M. and Dahake, P.G. (2013). Single cell protein- A 
review. International Journal for Pharmaceutical Research Scholars, 2(4), 472485.

Subramaniyam, R. and Vimala, R. (2012). Solid state and submerged fermentation for the production of bioactive substances: A comparative study. International Journal of Science and Nature, 3(3), 480-486.

Suman, G., Nupur, M., Anuradha, S. and Pradeep, B. (2015). Single cell protein production: A Review. International Journal of Current Microbiology and Applied Science, 4(9), 251262.

Ugalde, U.O. and Castrillo, J.I. (2002). Single cell proteins from fungi and yeasts. Applied Mycology and Biotechnology, 2, 123-149.
Zhou, Y.-M., Chen, Y.-P., Shen, Y., 2017. Single cell protein-feed: Taking orange waste as raw material for fermentation, pp 323-335. In: Qiang, L. and Iong-zong, C.J. (Ed) Advanced materials and energy sustainability. World Scientific Publishing Co. Pte. Ltd, Wuhan, Hubei, China. https://doi.org/10.1142/9789813220393_0 041.

Yousufi, M.K. (2012). Impact of pH on the single cell protein produced on okara-wheat grit substrates using Rhizopus oligosporus and Aspergillus oryzae. IOSR Journal of Environmental Science, Toxicology and Food Technology, 1, 32-35. 